\title{
Contribution of liquid wastes from Beloyarsk NPP to contamination of Pyshma river basin in the Urals
}

\author{
Ye.N. Karavaeva and I.V. Molchanova
}

Institute of Plant and Animal Ecology of Ural Division of Russian Academy of Sciences, 8 Marta Street 202, 620219 Ekaterinburg, Russia

\begin{abstract}
We studied the distribution of radionuclides in the components of the swamp-river ecosystem into which weakly radioactive debalance water from the Beloyarsk nuclear Power Plant was discharged during 35 years. We estimated the influence of this ecosystem on the Olkhovka and Pyshma rivers connected with the swamp in the same hydrographic system. During operation of 3 units of the power station the content of ${ }^{60} \mathrm{Co},{ }^{90} \mathrm{Sr}$ and ${ }^{137} \mathrm{Cs}$ in the swamp water was $2.5,0.7$ and $15.6 \mathrm{~Bq} \mathrm{l^{-1 }}$ respectively. Concentration of ${ }^{60} \mathrm{Co}$ and ${ }^{137} \mathrm{Cs}$ in the sediments of the ecosystem under study was units and tens of $\mathrm{kBq} \mathrm{kg}^{-1}$ dry weight respectively, while concentration of ${ }^{90} \mathrm{Sr}$ was only tens - hundreds of $\mathrm{Bq} \mathrm{kg}{ }^{-1}$ dry weight. According to calculations about $3.7 \cdot 10^{12} \mathrm{~Bq}$ has deposited in bottom sediments. When the first two units of the power station were out of operation the content of radionuclides in the water and sediments decreased significantly as a result of a decreased discharge, natural radioactive decay and the washout into the river system. ${ }^{13} \mathrm{Cs}$ was the main pollutant of the Olkhovsk swamp-river ecosystem. Significant quantities of this radionuclide were discovered in bottom sediments of the Pyshma $50 \mathrm{~km}$ from the pollution source.
\end{abstract}

\section{INTRODUCTION}

Beloyarsk nuclear Power Plant named after Kurchatov (BNPP) is located in the Middle Urals, 60 km east from the city of Ekaterinburg. The first phase of BNPP consisting of two power units with graphitemoderated and water-cooled reactors on thermal neutrons of the type AMB-100 and AMB-200 was brought to the design capacity of $300 \mathrm{MWe}$ in 1969 and 1989 it was shut down. In 1980 the second phase consisting of a power unit $\mathrm{N} 3$ based on fast neutron reactor BN-600 was commissioned. It is still in operation. Five kilometers south-east from BNPP there is Olkhovsk swamp-river ecosystem which for many years has been contaminated with BNPP weakly radioactive debalance water. It involves Olkhovsk swamp, the adjacent boggy areas and a small river Olkhovka which flows from the swamp to the Pyshma river. The Pyshma belongs to the Ob-Irtysh system. A $200 \mathrm{~m}$ long artificial canal brings wastes from the BNPP to the swamp. The square of the swamp is $0.3 \mathrm{~km}^{2}$.The drainage from the swamp to Olkhovka exceed 5 times the wastes from the BNPP. The thickness of the sediments in the Olkhovsk swamp is 1$1.5 \mathrm{~m}$, with maximum peat depth $-3.5 \mathrm{~m}$. The Olkhovsk swamp-river ecosystem can be called "a trouble spot".

\section{MATERIALS AND METHODS}

Since 1978 we have systematically studied the Olkhovsk swamp-river ecosystem. Every year samples of water, plants and bottom sediments were taken directly from the canal, the Olkhovsk swamp, the source and the mouth of the Olkhovka river, as well from the Pyshma river $500 \mathrm{~m}$ upstream and downstream after the confluence with the Olkhovka. The collected samples of plants and sediments were dried up to the dry weight. Then the sediments were fined and sieved ( $1 \mathrm{~mm}$ mesh size). The plants were burnt to ashes at $500^{\circ} \mathrm{C}$. The samples of water (40 I) were filtered to remove macroimpurity and then evaporated to dryness. The dry precipitates were burnt to ashes at $500^{\circ} \mathrm{C}$. The content of ${ }^{90} \mathrm{Sr}$ in the samples was estimated radiochemically by its daughter ${ }^{90} \mathrm{Y}$. The limit of ${ }^{90} \mathrm{Sr}$ detection was $1 \mathrm{~Bq} \mathrm{~kg}^{-1}$. The error did not exceed $20 \%$. The content of ${ }^{137} \mathrm{Cs}$ was measured by NaI(TI) gamma-spectroscopy. The statistical error was below $30 \%$. The limit of ${ }^{137} \mathrm{Cs}$ detection was $10 \mathrm{~Bq} \mathrm{~kg}^{-1}$. 


\section{RADIONUCLIDES IN THE COMPONENTS OF THE OLKHOVSK SWAMP-RIVER ECOSYSTEM}

\section{1. Water}

In the period of 1978 to 1986 the Olkhovsk swamp-river ecosystem periodically suffered from the influence of the three power units of the BNPP. At that time the concentration of radionuclides in the water within the distance the discharge canal to the Olkhovka mouth could vary ten times (Table 1). The average concentration of ${ }^{60} \mathrm{Co},{ }^{90} \mathrm{Sr}$ and ${ }^{137} \mathrm{Cs}$ in this period amounted to $2.5,0.7$ and $15.6 \mathrm{~Bq} \mathrm{l}^{-1}$, respectively. This is approximately 20,5 and 75 times higher then their levels in the Pyshma river before its confluence with the Olkhovka river.

Table 1. Radionuclides in the water of the Olkhovsk swamp-river ecosystem, $\mathrm{Bq} \mathrm{l}^{-1}$; in brackets yearly oscillations from 1978 to 1986

\begin{tabular}{|l|c|c|c|}
\hline Locations & ${ }^{60} \mathrm{Co}$ & ${ }^{90} \mathrm{Sr}$ & ${ }^{\top 3 T} \mathrm{Cs}$ \\
\hline $\begin{array}{l}\text { Discharge canal } \\
\text { Olkhovsk swamp: }\end{array}$ & $2.6(2.2-6.4)$ & $0.6(0.1-1.2)$ & $10.0(2.8-28.3)$ \\
beginning & $3.3(2.6-7.6)$ & $0.8(0.1-1.6)$ & $16.6(2.3-49.2)$ \\
middle & $2.8(1.5-10.1)$ & $0.9(0.1-1.7)$ & $20.7(4.1-43.4)$ \\
Olkhovka river: & & & \\
source & $2.8(1.2-7.6)$ & $0.8(0.2-2.5)$ & $16.0(9.7-35,0)$ \\
mouth & $1.3(1.1-2.6)$ & $0.4(0.2-1.0)$ & $10.0(2.4-16.0)$ \\
Pyshma river: & & & \\
$0.5 \mathrm{~km}$ upstream & $0.1(0.1-0.2)$ & $0.1(0.1-0.2)$ & $0.2(0.1-0.4)$ \\
$0.5 \mathrm{~km}$ downstream & $0.1(0.1-0.3)$ & $0.2(0.1-0.3)$ & $1.3(0.1-4.4)$ \\
\hline
\end{tabular}

After the confluence with the Olkhovka river the concentration of ${ }^{90} \mathrm{Sr}$ and ${ }^{137} \mathrm{Cs}$ in the Pyshma river increased as compared with above levels. This is evidence of the fact that radionuclides are carried out from the Olkhovsk swamp by the waters of the Olkhovka to the Pyshma. More or less constant radionuclides concentration in water samples taken along the flow from discharge canal to the Olkhovka mouth speaks in favour of radionuclides migration without essential dilution.

As the mobility of radionuclides in natural ecosystems depends on their condition in solution, it was interesting to elucidate in which form - water-soluble or colloid - they migrated with the liquid runoff. The results of the investigation showed that the main part of ${ }^{90} \mathrm{Sr}(95-99 \%)$ and ${ }^{137} \mathrm{Cs}(88-93 \%)$ migrated in a soluble form, while in a colloid fraction the content of ${ }^{90} \mathrm{Sr}$ did not exceed 5 and that of ${ }^{137} \mathrm{Cs}-12 \%$. Similar data are reported from the Rhone river [1].

After the first phase of the BNPP was shut down the entry of ${ }^{60} \mathrm{Co}$ and ${ }^{137} \mathrm{Cs}$ into the Olkhovka swamp-river ecosystem sharply reduced. Thus, in 1994 the average concentration of ${ }^{60} \mathrm{Co}$ in the water within the distance the discharge canal to the Olkhovka mouth was 0.25 , that of ${ }^{137} \mathrm{Cs}-0.70 \mathrm{~Bq} \mathrm{l}^{-1} \cdot{ }^{90} \mathrm{Sr}$ concentration in the water of the swamp and the Olkhovka river almost did not change in this period compared with earlier period of investigations and amounted to $1 \mathrm{~Bq} \mathrm{l}^{-1}$. In 1999 concentrations of all radionuclides in the water at the swamp outlet decreased to $0.1-0.2 \mathrm{~Bq} \mathrm{l}^{-1}$.

\subsection{Sediments}

It is known that river ground and bottom sediments of basins have high sorption capacity and can absorb and firmly hold microquantities of chemical elements [2,3]. Therefore, we studied the role of bottom sediments in radionuclide migratory processes in the swamp-river ecosystem. Starting from 1978 till 1986 concentration of ${ }^{137} \mathrm{Cs}$ in sediments of the ecosystem under study accounted for tens, while of ${ }^{60} \mathrm{Co}$ and ${ }^{90} \mathrm{Sr}$, respectively, units or tens-hundreds parts of $\mathrm{kBq} \mathrm{kg}^{-1}$ dry weight (Table 2). Maximum concentration of ${ }^{60} \mathrm{Co}$ of $60,{ }^{90} \mathrm{Sr}$ of 4 and ${ }^{137} \mathrm{Cs}$ of $110 \mathrm{kBq} \mathrm{kg}^{-1}$ is found in silt formed at the beginning of the swamp, in the place of contact between the boggy and waste waters. Concentration of radionuclides in the bottom sediments of the Pyshma river decreased one or two orders of magnitude, being less in sand than in silt. 
The lowest concentration of radionuclides, especially of ${ }^{137} \mathrm{Cs}$, the main pollutant of bottom sediments, was observed in the section of the Pyshma $0.5 \mathrm{~km}$ upstream from the mouth of the Olkhovka river.

During later years of the research ${ }^{60} \mathrm{Co}$ and ${ }^{90} \mathrm{Sr}$ concentrations in the swamp bottom sediments and ground of the Olkhovka amounted to 0.01 and $0.1 \mathrm{kBq} \mathrm{kg}^{-1}$; towards 1999 their content in most cases was at the limit of their discovery. ${ }^{137} \mathrm{Cs}$ remained the main pollutant of the ecosystem under study but even its content markedly reduced in the bottom sediments since 1989 (Table 3).

Table 2. Radionuclides in the bottom sediments of the Olkhovsk swamp-river ecosystem, $\mathrm{kBq} \mathrm{kg}^{-1}$ dry weight; in brackets yearly oscillations from 1978 to 1986

\begin{tabular}{|l|c|c|c|c|}
\hline Locations & Bottom sediments & ${ }^{60} \mathrm{Co}$ & ${ }^{90} \mathrm{Sr}$ & ${ }^{137} \mathrm{Cs}$ \\
\hline Discharge canal & Sand & $4.0(1.6-6.0)$ & $0.07(0.02-0.10)$ & $16.0(7.0-25.0)$ \\
& Silt & $5.0(3.0-46.0)$ & $0.20(0.06-0.27)$ & $22.0(18.0-28.0)$ \\
Olkhovsk swamp: & & & & \\
beginning & Silt & $34.0(1.0-60.0)$ & $1.80(0.48-3.8)$ & $58.0(9.0-112.0)$ \\
middle & Silt & $3.0(1.0-7.0)$ & $1.20(0.07-3.4)$ & $27.0(7.2-65.0)$ \\
Olkhovka river: & & & & \\
source & Sand & $0.12(0.10-0.15)$ & $0.03(0.02-0,15)$ & $20.0(10.0-30.0)$ \\
& Silt & $1.40(0.77-2.30)$ & $0.19(0.06-0.87)$ & $30.0(8.0-51.0)$ \\
mouth & Sand & $0.30(0.14-0.50)$ & $0.06(0.01-0.17)$ & $16.0(3.0-26.0)$ \\
& Silt & $0.90(0.15-2.10)$ & $0.14(0.01-0.24)$ & $34.0(7.0-86.0)$ \\
Pyshma river: & & & & \\
0.5 km upstream & & & & $0.09(0.03-0.20)$ \\
& Sand & $0.04(0.01-0.10)$ & $0.01(0,005-0,02)$ & $0.37(0.10-0.97)$ \\
0.5 km downstream & Silt & $0.05(0.02-0.08)$ & $0.01(0,003-0,04)$ & $0.21(0.15-0.33)$ \\
& Sand & $0.03(0.01-0.10)$ & $0.01(0,003-0,02)$ & $3.00(0.15-3.90)$ \\
\hline
\end{tabular}

Table $3 .{ }^{137} \mathrm{Cs}$ in the bottom sediments of the Olkhovsk swamp-river ecosystem, $\mathrm{kBq} \mathrm{kg}^{-1}$ dry weight

\begin{tabular}{|l|c|c|c|c|}
\hline \multirow{2}{*}{ Locations } & Bottom sediments & \multicolumn{3}{|c|}{ Years } \\
\cline { 2 - 4 } & Sand & 1989 & 1994 & 1999 \\
\hline Discharge canal & Silt & $29.0 \pm 2.8$ & - & - \\
Olkhovsk swamp: & & & $8.5 \pm 0.8$ & $3.2 \pm 0.9$ \\
beginning & Silt & $64.7 \pm 5.4$ & $4.5 \pm 0.3$ & $15.4 \pm 5.1$ \\
middle & Silt & $26.7 \pm 10.0$ & $10.0 \pm 0.1$ & - \\
& & & & \\
Olkhovka river: & & & & \\
source & Sand & $18.8 \pm 7.1$ & $11.7 \pm 0.5$ & - \\
& Silt & $36.2 \pm 6.7$ & $19.1 \pm 1.6$ & $6.2 \pm 1.3$ \\
mouth & Sand & $18.9 \pm 2.0$ & $7.0 \pm 0.1$ & - \\
& Silt & $27.8 \pm 11.2$ & $9.4 \pm 2.9$ & $14.0 \pm 3.0$ \\
Pyshma river: & & & & $0.04 \pm 0.009$ \\
$0.5 \mathrm{~km}$ upstream & & & & $0.12 \pm 0.01$ \\
$0.5 \mathrm{~km}$ downstream & Sand & $0.2 \pm 0.02$ & $0.05 \pm 0.001$ & $0.2 \pm 0.007$ \\
& Silt & $1.2 \pm 0.08$ & $0.07 \pm 0.008$ & $1.1 \pm 0.35$ \\
\hline
\end{tabular}

To characterize the sorption ability of bottom sediments we used the value which was called the distribution coefficient (DC), i.e. the ratio between the averaged over the observation period concentration of a radionuclide in the ground and the water. Thus, DC for ${ }^{60} \mathrm{Co}$ changed from 45 to 10360 , for ${ }^{90} \mathrm{Sr}$ - from 25 to 2570 , for ${ }^{137} \mathrm{Cs}$ - from 160 to 3430 . This might be connected with the chemical and mineralogical composition of the ground in various areas of the system under study. On the whole, DC was lower in sand sediments than in the silt, the value for ${ }^{90} \mathrm{Sr}$ was lower than for ${ }^{60} \mathrm{Co}$ and ${ }^{137} \mathrm{Cs}$. Bottom sediments in the beginning of the swamp had the highest accumulation ability. 
The research of vertical distribution of radionuclides in the depth of bottom sediments showed that maximum concentrations were in the $25-\mathrm{cm}$ upper layer, the vain quantity of radionuclides being in the $50-\mathrm{cm}$ layer contacting with the waste water passing through the swamp. At the depth of $100-125 \mathrm{~cm}$ only units percent from the total storage in the bottom sediments profile were discovered.

\section{RADIONUCLIDES IN THE WATER AND BOTTOM SEDIMENTS. OF THE PYSHMA RIVER}

According to our calculation with the account for natural radioactive decay bottom sediments of the Olkhovsk swamp contain at present ca. $0.15 \cdot 10^{12} \mathrm{~Bq}$ of ${ }^{60} \mathrm{Co}, 0.1 \cdot 10^{12} \cdot \mathrm{Bq}$ of ${ }^{90} \mathrm{Sr}$ and $3.5 \cdot 10^{12} \mathrm{~Bq}$ of ${ }^{137} \mathrm{Cs}$. In fact the values are less because in the period from 1978 to 1989 about $0.7 \%$ of ${ }^{60} \mathrm{Co}, 3.0 \%$ of ${ }^{90} \mathrm{Sr}$ and $1.5 \%$ of ${ }^{137} \mathrm{Cs}$ was annually carried out into the open hydrographic system. This allowed to predict the appearance of radionuclides in the river system. We investigated the Pyshma water area, Water and bottom sediments were sampled for the space of $80 \mathrm{~km}$ downstream from the Olkhovka mouth. The effect of the Olkhovka river on the content of radionuclides in the Pyshma water was insignificant; 8$13 \mathrm{~km}$ downstream the background level typical of the Ural region was observed. For the Pyshma bottom sediments, the maximum $\left(1.3-2.3 \mathrm{kBq} \mathrm{kg}^{-1}\right){ }^{137} \mathrm{Cs}$ content was recorded in silt at a distance of 0.5 and 13 $\mathrm{km}$ from the Olkhovka mouth (Table 4). Further downstream ${ }^{137} \mathrm{Cs}$ concentration in silt varied from 0.2 to $0.8 \mathrm{kBq} \mathrm{kg}^{-1}$. Notable quantities of ${ }^{137} \mathrm{Cs}$ were reported for silty sediments of the Pyshma river even at a distance of $50 \mathrm{~km}$ from confluence its with the Olkhovka. Only $80 \mathrm{~km}$ downstream of the Pyshma ${ }^{137} \mathrm{Cs}$ content in the silt approached the level typical of the area outside the effect of the Olkhovsk swamp. ${ }^{137} \mathrm{Cs}$ concentration in the sand sediments of the Pyshma investigated area decreased downstream from 0.2 to $0.007 \mathrm{kBq} \mathrm{kg}^{-1}$.

Table $4 .{ }^{137} \mathrm{Cs}$ in the bottom sediments of the Pyshma river, $\mathrm{kBq} \mathrm{kg}^{-1}$ dry weight

\begin{tabular}{|c|c|c|c|c|}
\hline \multirow{3}{*}{$\begin{array}{l}\text { Distance from the } \\
\text { Olkhovka river } \\
\text { mouth, km }\end{array}$} & \multicolumn{4}{|c|}{ Years } \\
\hline & \multicolumn{2}{|c|}{1995} & \multicolumn{2}{|c|}{1999} \\
\hline & Sand & Silt & Sand & Silt \\
\hline $\begin{array}{l}\text { Upstream the } \\
\text { Pyshma river } \\
\text { 35 }\end{array}$ & $0.04 \pm 0.008$ & $0.05 \pm 0.005$ & - & - \\
\hline $\begin{array}{l}\text { Downstream the } \\
\text { Pyshma river }\end{array}$ & & & & \\
\hline 0.5 & $0.20 \pm 0.010$ & $1.3 \pm 0.04$ & $0.2 \pm 0.01$ & $1.1 \pm 0.03$ \\
\hline 8 & $0.16 \pm 0.005$ & $0.7 \pm 0.01$ & $0.1 \pm 0.01$ & $2.2 \pm 0.07$ \\
\hline 13 & $0.19 \pm 0.003$ & $1.4 \pm 0.05$ & $0.2 \pm 0.01$ & $2.3 \pm 0.13$ \\
\hline 18 & - & $0.2 \pm 0.01$ & $0.2 \pm 0.02$ & $0.8 \pm 0.10$ \\
\hline 25 & $0.13 \pm 0.020$ & $0.7 \pm 0.07$ & - & \\
\hline 35 & $0.07 \pm 0.007$ & $0.7 \pm 0.04$ & $0.06 \pm 0.007$ & $0.4 \pm 0.04$ \\
\hline 50 & $0.01 \pm 0.001$ & $0.2 \pm 0.01$ & - & $0.3 \pm 0.04$ \\
\hline 80 & - & - & $0.01 \pm 0.001$ & $0.07 \pm 0.03$ \\
\hline
\end{tabular}

${ }^{90} \mathrm{Sr}$ content in the Pyshma bottom sediments was insignificant at a distance of $0.5 \mathrm{~km}$ from the Olkhovka mouth (4-5 $\mathrm{Bq} \mathrm{kg}^{-1}$ ); further downstream this radionuclide was not detected in most sites.

\section{CONCLUSION}

Within the $30 \mathrm{~km}$ zone of the Beloyarsk nuclear Power Plant there is the Olkhovsk swamp-river ecosystem which for many years has been polluted with BNPP weakly radioactive debalance water. Such water enters the swamp through an artificial canal. The swamp has an outlet to the open hydrographic system; it is connected with the river system Pyshma-Tura-Tobol through a small river Olkhovka. Manyyear exploitation of the natural ecosystem as a filter caused contamination of all its components with 
radionuclides. The main pollutant of the swamp-river ecosystem is ${ }^{137} \mathrm{Cs}$, the total storage of which in bottom sediments of the swamp is $3.5 \cdot 10^{12} \mathrm{~Bq}$ at present. Direct measurement and calculations have shown that $1.5 \%$ of ${ }^{137} \mathrm{Cs}$ from its storage in bottom sediments annually enters the open hydrographic system. As a result, the Olkhovka bottom sediments all along the river $(3 \mathrm{~km})$ are characterized by an increased $\left(20-30 \mathrm{kBq} \mathrm{kg}^{-1}\right)$ content of this radionuclide. Notable quantities of ${ }^{137} \mathrm{Cs}$ are reported for the Pyshma bottom sediments even at a distance of $50 \mathrm{~km}$ from the pollution source. The analyses of the data obtained has the trend of contamination to progress downstream the Pyshma, which may affect the condition of the Pyshma-Tura-Tobol river system.

\section{Acknowledgment}

This study is supported by the Russian Foundation for Basic Research (project 00-05-65401).

\section{References}

[1] A. Grauby, in Atti. XX Congr. Naz. Assoc. Ital. Fis. Sanit. Prot. Control. Radiaz., Bologna, 1977, (Bologna, 1978), pp. 1-21.

[2] Ye. A. Timofeeva-Resovskaya, Distribution of Radioisotopes in the Main Components of Freshwater Basins (Ural Division of Sciences of Academy USSR, Sverdlovsk, 1963), $77 \mathrm{p}$.

[3] N. V. Kulikov, M. Ya. Chebotina, Radioecology of Freshwater Biosystems (Ural Division of Sciences of Academy USSR, Sverdlovsk, 1988), $126 \mathrm{p}$. 